\title{
STANOWISKO ŚWIADKÓW JEHOWY WOBEC WYBRANYCH WSPÓŁCZESNYCH PROCEDUR MEDYCZNYCH W ŚWIETLE PRAWA POLSKIEGO ${ }^{1}$
}

\section{WPROWADZENIE}

Rzeczpospolita Polska jest państwem świeckim, które w konstytucji wyraża zasadę poszanowania wolności religijnej zarówno w aspekcie instytucjonalnym jak i indywidualnym. Art. 25 Konstytucji RP z dnia 2 kwietnia 1997 r. ${ }^{2}$ gwarantuje kościołom i innym związkom wyznaniowym prawo do działania w obszarze prawa polskiego przy utrzymaniu zasady równouprawnienia podmiotów wyznaniowych. Natomiast art. 53 ustawy zasadniczej stanowi gwarancję przyznania każdemu wolności sumienia i religii, czyli między innymi prawa do uzewnętrzniania przekonań religijnych indywidualnie, zbiorowo, publicznie czy prywatnie chociażby poprzez uprawianie kultu, praktykowanie czy nauczanie. Rozwinięciem konstytucyjnych gwarancji poszanowania wolności religijnej jest ustawa z dnia 17 maja 1989 r. o gwarancjach

* Dr, Wydział Prawa i Administracji, Uniwersytet Jagielloński, ul. Gołębia 9, 31-007 Kraków, e-mail: k.krzysztofek@uj.edu.pl

${ }^{1}$ Tekst jest uaktualnioną wersją napisanego przeze mnie artykułu zatytułowanego: Stanowisko Świadków Jehowy wobec wybranych współczesnych procedur medycznych opublikowanego w książce: Sprzeciw sumienia w praktyce medycznej - aspekty etyczne i prawne, red. Piotr Stanisz, Jakub Pawlikowski, Marta Ordon (Lublin: Wydawnictwo KUL, 2014), 41-58.

${ }^{2}$ Dz. U. Nr 78, poz. 483 z późn. zm. 
wolności sumienia $i$ wyznania ${ }^{3}$. I właśnie na wspomnianej ustawie opiera się dzisiejsza działalność Świadków Jehowy w Polsce, gdyż Świadkowie Jehowy są zarejestrowanym związkiem wyznaniowym wpisanym pod nr 34 do Rejestru kościołów i innych związów wyznaniowych prowadzonego przez Ministra Spraw Wewnętrznych i Administracji, w którego gestii od dnia 16 listopada 2015 r. ${ }^{4}$ pozostają sprawy wyznaniowe. Wyznawcy Jehowy w Polsce działają dziś pod nazwą „Świadkowie Jehowy w Polsce”. Organizacja została zarejestrowana w dniu 31 stycznia 1990 r. ${ }^{5}$ Ale historia Świadków Jehowy sięga dużo dalej w przeszłość. Za założyciela dzisiejszej grupy religijnej Świadków Jehowy uważa się urodzonego w 1852 r. w Pittsburghu Charlsa Taze Russella. Był on wychowywany w duchu prezbiteriańskim, ale w wieku 16 lat odrzucił wiarę wyznawaną przez rodzinę i przechodząc kolejno przez różne etapy kształtowania swego światopoglądu religijnego ostatecznie przyłączył się do adwentystów. Równocześnie rozpoczął, początkowo w wąskim gronie rodziny i znajomych, samodzielne badanie Pisma Świętego. Celem owych analiz było wykazanie niezgodności pomiędzy nauką głoszoną przez religię chrześcijańską, a tekstem Pisma Świętego. Formalnoprawne powstanie grupy religijnej zainicjowanej przez Russella nastąpiło w 1914 r. pod nazwą: „Międzynarodowe Stowarzyszenie Badaczy Pisma Świętego"6. Zasady, na których

${ }^{3}$ Tekst jedn.: Dz. U. z 2005 r., Nr 231, poz. 1965.

${ }^{4}$ Rozporządzenie Rady Ministrów z dnia 20 listopada 2015 r. w sprawie utworzenia Ministerstwa Spraw Wewnętrznych i Administracji, Dz. U. z 2015 r., poz. 1946.

${ }^{5}$ Zob. Rejestr kościołów i innych związków wyznaniowych dostępny pod adresem: https://mac.gov.pl/files/e-rejestr_eb_24.09_2015.pdf [dostęp: 06.11.2015]. W momencie rejestracji Świadkowie Jehowy zostali wpisani do rejestru pod nazwą „Strażnica Towarzystwo Biblijne i Traktatowe. Zarejestrowany Związek Wyznania Świadków Jehowy w Polsce". W maju 2014 r. nastąpiła za zgodą Ciała Kierowniczego zmiana statutu tej osoby prawnej, która przyjęła obecną nazwę czyli „Świadkowie Jehowy w Polsce”. Zob. http://watchtower-forum.pl/topic/5325-nowy-statut-\%C5\%9Bwiadk\%C3\%B3w-w-polsce/ [dostęp: 26.09.2015]

${ }^{6}$ Elizeusz Bagiński, Siewcy kąkolu; historia i wierzenia Świadków Jehowy (Kraków: Wydawnictwo Karmelitów Bosych, 1998), 10-19. Nazwa organizacji zmieniała się kilkakrotnie. W 1884 r. ruch przybrał nazwę: „Stowarzyszenie Strażnicy Syjońskiej”; w 1896 r.: „Strażnica Towarzystwo Biblijne i Traktatowe”; w 1909 r.: „Stowarzyszenie Trybuny Ludów”, w 1913 r.: „Międzynarodowe Stowarzyszenie Badaczy Pisma Świętego”; a w 1931 r.: „Organizacja Świadków Jehowy”. Zob. Andrzej Elkowicz, Krótka historia 
Badacze Pisma Świętego oparli swoją wiarę, wywodzili oni bezpośrednio z Biblii, uważając, że jej słów nie należy interpretować, ale pojmować w sposób dosłowny.

Początkowo niewielka grupa badaczy przekształciła się w sprawnie działający podmiot, na czele którego stali prezydenci. Pierwszym z nich był założyciel grupy Charles T. Russell, kolejnym od 1917 r. Joseph Franklin Rutherford - dotychczasowy radca prawny Towarzystwa Strażnica. Za czasów jego władzy wprowadzone zostały liczne reformy życia członków Towarzystwa. Przykładowo Rutherford zakazał noszenia brody, posługiwania się obrazami świętych, zniósł święta religijne, zakazał obchodzenia imienin, wprowadził nazwę „Organizacja Świadków Jehowy”. Trzecim prezydentem został wybrany Nathan Knorr, który prezydenturę w Organizacji objął w 1942 r. i kontynuował do 1977 r. ${ }^{7}$ Powołał on do życia Ciało Kierownicze, które w doktrynie wyznawców Jehowy jest uważane za realizację słów wypowiedzianych przez Chrystusa na kartach Ewangelii św. Mateusza: „Któż jest tym sługą wiernym i roztropnym, którego pan ustanowił nad swoją służbą, żeby na czas rozdał jej żywność?"8. Wedle Świadków Jehowy Ciało Kierownicze jest sługą wiernym i roztropnym, którego rolą jest wykładanie Pisma Świętego będącego pokarmem dla wiernych ${ }^{9}$. Czwartym prezydentem Organizacji był do 1992 r. Frederick William Franz, piątym do 2003 r. był Milton George Henschel ${ }^{10}$, a obecnie na czele Towarzystwa stoi Don Alden Adams.

Już na początku należy wyraźnie podkreślić, że Świadkowie Jehowy są bardzo mocno przywiązani do nauk głoszonych przez Ciało Kierownicze, przez swoich przywódców, którzy twierdzą, że podstawy doktryny wywodzą z literalnego rozumienia słów Pisma Święte-

zmian nauki Świadków Jehowy (Warszawa: Wydawnictwo Kompas II, 2004), 19; Elizeusz Bagiński, Świadkowie Jehowy; pochodzenie-historia-wierzenia (Kraków: Wydawnictwo Karmelitów Bosych, 1997), 63.

${ }^{7}$ Elkowicz, Krótka historia, 16-20.

${ }^{8}$ Mt. 24: 45, Pismo Święte Starego i Nowego Testamentu, Biblia Tysiaclecia (PoznańWarszawa: Wydawnictwo Pallottinum, 1995), 1152.

${ }^{9}$ Szerzej na temat Ciała Kierowniczego zob.: Elizeusz Bagiński, Świadkowie Jehowy od wewnątrz (Kraków: Wydawnictwo Karmelitów Bosych, 1999), 22-51.

${ }^{10}$ Elkowicz, Krótka historia, 23-24. 
go. I w oparciu o dosłowne brzmienie Świętej Księgi kształtują swoje poglądy na różne zagadnienia, w tym na te, o charakterze medycznym. Kolejni przywódcy na nowo odkrywali wolę Jehowy wyrażoną na kartach biblijnych. Niejednokrotnie zdarzało się, że zmiany w doktrynie Świadków Jehowy były oparte na przyjęciu całkowicie odmiennego stanowiska - czynności, które dotąd były zakazane uznawano za dopuszczalne. W latach osiemdziesiątych XX w. w celu uzasadnienia faktu częstego zmieniania poglądu na jedno i to samo zagadnienie w łonie Ciała Kierowniczego wykształcił się pogląd odczytywania słów Pisma Świętego w drodze ,halsowania”"11 - „Niektórym jednak wydaje się, że ścieżka ta nie zawsze prowadziła prosto przed siebie. Wyjaśnienia podawane przez widzialną społeczność ludu Jehowy zawierają niekiedy poprawki, które jak gdyby nawracały do punktu wyjścia, do dawniejszych poglądów. [...] Nasuwa się tu porównanie z tym, co w środowisku wodniaków bywa nazywane «halsowaniem». Manewrując osprzętem, żeglarze potrafią zmusić statek do zwrotów w prawo i w lewo, tam i z powrotem ale cały czas posuwają się w upatrzonym kierunku pomimo przeciwnego wiatru"12. $\mathrm{Na}$ dzień dzisiejszy poglądy Świadków Jehowy obowiązują w kształcie określonym przez Ciało Kierownicze, a prezentowane są w dwóch głównych czasopismach Organizacji - „Strażnica” i „Przebudźcie się!’”.

Podkreślić trzeba, że tylko wypełnianie wszystkich nakazów i wystrzeganie się tego co zabronione, gwarantuje Świadkom Jehowy możliwość zbawienia. Dlatego też nierzadko zdarza się, że rodzice działając w ufności i wierze, do której wyznawania obliguje ich przynależność do grupy religijnej Świadków Jehowy, są w stanie poświęcić życie swojego dziecka odmawiając zastosowania w stosunku do niego jednej z procedur leczniczych mogących uratować mu życie, byle tylko nie naruszyć zasad doktrynalnych, a tym samym nie zamknąć sobie i dziecku drogi do zbawienia.

Na problematykę stanowiska Świadków Jehowy wobec współczesnych procedur medycznych składa się wiele zagadnień. W niniejszej pracy zostanie uwzględniona postawa Świadków Jehowy wyłącznie

\footnotetext{
${ }^{11}$ Bagiński, Świadkowie Jehowy od wewnątrz, 42.

12 „Coraz jaśniej na ścieżce sprawiedliwych,” Strażnica 18 (1982): 19.
} 
wobec tych świadczeń medycznych, które są istotne z racji ich wagi dla życia i zdrowia pacjenta oraz z uwagi na to, że stosunek Świadków Jehowy do nich budzi najwięcej kontrowersji. Analizie zostanie poddana postawa wyznawców Jehowy wobec dokonywania transfuzji krwi, przeszczepiania narządów czy szpiku kostnego oraz przyjmowania szczepionek.

\section{STANOWISKO ŚWIADKÓW JEHOWY WOBEC TRANSFUZJI KRWI}

Zdecydowanie najbardziej kontrowersyjnym zakazem w aspekcie medycznym funkcjonującym w obrębie Świadków Jehowy, ale równocześnie najlepiej opisanym w literaturze przedmiotu, jest zakaz przyjmowania transfuzji krwi. Zakaz ten wywodzony jest ze słów Pisma Świętego, które głosi w Księdze Kapłańskiej: „Gdziekolwiek będziecie mieszkać, nie wolno wam spożywać żadnej krwi: ani krwi ptaków, ani krwi bydląt. Ktokolwiek spożywa jakąkolwiek krew, będzie wykluczony spośród swego ludu"13; ,Jeżeli kto z domu Izraela albo spośród przybyszów, którzy osiedlili się między nimi, będzie spożywał jakąkolwiek krew, zwrócę oblicze moje przeciwko temu człowiekowi spożywającemu krew i wyłączę go spośród jego ludu. Bo życie ciała jest we krwi [...] Bo życie wszelkiego ciała jest we krwi jego [...]"14. Ponadto odnośnie zakazu spożywania krwi wzmianki znajdują się również w Księdze Powtórzonego Prawa: „Ale się wystrzegaj spożywania krwi, bo we krwi jest życie, i nie będziesz spożywał życia razem z ciałem. Nie będziesz jej spożywał, ale jak wodę na ziemię ją wylejesz. Nie spożyjesz jej, aby ci dobrze było i synom twoim po tobie, za to, że uczyniłeś, co słuszne jest w oczach Pana"15. W związku z powyższym członkom grupy wyznaniowej Świadków Jehowy zabroniono przyjmowania transfuzji krwi, która w rozumieniu przywódców Organizacji jest równoznaczna z jej spożywaniem. Ale trzeba podkreślić,

${ }^{13}$ Księga Kapłańska 7: 26-27, Pismo Święte Starego i Nowego Testamentu, Biblia Tysiąclecia, 112.

${ }^{14}$ Księga Kapłańska 17: 10-11, 14, Tamże, 124.

${ }^{15}$ Księga Powtórzonego Prawa 12: 23-25, Tamże, 185. 
że zakaz przyjmowania transfuzji krwi nie obowiązywał Świadków Jehowy od początku istnienia Organizacji. Jej założyciel Russell oraz jego następca Rutherford nie byli przeciwni przetaczaniu krwi, a ten ostatni wręcz ją chwalił ${ }^{16}$. Szczególnie często posługiwano się kazusem kobiety, która przypadkowo postrzeliła się w serce i dzięki transfuzji krwi przeżyła i cieszyła się dobrym zdrowiem. Jednak trzeci prezydent Organizacji, Nathan Knorr z dniem 1 lipca 1945 r. wprowadził zakaz transfuzji krwi wśród Świadków Jehowy ${ }^{17}$. Dodatkowym uzasadnieniem dla zakazu transfuzji krwi u Świadków Jehowy jest, jak twierdzą przywódcy Organizacji, ryzyko np. przeniesienia choroby związane z tym zabiegiem ${ }^{18}$. Na łamach czasopisma „Strażnica” w 1967 r. transfuzja została przyrównana do ludożerstwa: „Wyobraź sobie, że miałbyś jeść ciało innego człowieka! Okropność! A czy picie krwi ludzkiej jest mniej okropne? Czy coś w tym zmienia fakt, że nie przyjmuje się jej przez usta, lecz wprowadza do ciała bezpośrednio przez żyły? W żadnym wypadku!" 19 . Takie stanowisko jest aktualne pośród wyznawców Jehowy i dzisiaj. Z tym, że nie zgadzają się oni na przyjęcie pełnej krwi, czyli krwinek czerwonych, krwinek białych, płytek krwi i osocza, a także na autotransfuzję, nie oddają również krwi jako dawcy. Natomiast sumieniu wyznawców pozostawiona została możliwość transfuzji frakcji krwi. Ewentualnie dopuszczają oprócz frakcji krwi możliwość poddania się zabiegom operacyjnym w zamkniętym obiegu krwi, tak aby krew nie opuszczała krwioobiegu ${ }^{20}$.

${ }^{16}$ Elkowicz, Krótka historia, 19.

17 Tamże, 21.

${ }^{18}$ Szerzej na temat stanowiska Świadków Jehowy wobec transfuzji krwi zob.: Jak krew może ocalić twoje życie, dostępny pod adresem: http://www.jw.org/pl/publikacje/ ksi\%C4\%85\%C5\%BCki/krew/JAK-KREW-MO\%C5\%BBE-OCALI\%C4\%86-TWOJE-\% C5\%BBYCIE/ [dostęp: 24.09.2015]

19 „Przejawianie dojrzałości - ochroną; Powstrzymywanie się od krwi,” Strażnica 17 (1967): 5 .

${ }^{20}$ Tadeusz Wiwatowski, „Stanowisko Świadków Jehowy wobec opieki medycznej,” w: Małgorzata Szeroczyńska, Bogusława Wołoszczuk-Gębicka, i Tadeusz Wiwatowski, Zabiegi chirurgiczne u Świadków Jehowy; aspekty medyczne i prawne (Warszawa: Wydawnictwo Emu, 2001), 10. Zob. również: Czesław Żaba, Paweł Świderski, Zbigniew Żaba, Aneta Klimberg, i Zygmunt Przybylski, ,Zgoda Świadków Jehowy na leczenie preparatami krwi - aspekty prawne i etyczne," Archiwum Medycyny Sadowej i Kryminologii LVII (2007): 138-143; Bogusława Wołoszczuk-Gębicka, Medyczne aspekty ,,bezkrwawej chirurgii”, w: 


\section{STANOWISKO ŚWIADKÓW JEHOWY \\ WOBEC TRANSPLANTACJI ORGANÓW I SZPIKU KOSTNEGO}

Stanowisko Świadków Jehowy w kwestii możliwości przeprowadzania zabiegów transplantacji organów zmieniało się na przestrzeni czasu. Po raz pierwszy wzmianka na temat transplantacji narządów wśród Świadków Jehowy pojawiła się w 1960 r. przy okazji omawiania działania organizmu ludzkiego. W czasopiśmie wyznawców Jehowy „Przebudźcie się!” wychwalając pracę nerek wskazywano, że: „Nawet nerka przetransplantowana $\mathrm{z}$ innego człowieka natychmiast rozpoczyna prace i spełnia swoje zadanie nadal dobrze i punktualnie"21. W $1962 \mathrm{r}$. na łamach czasopisma Świadków Jehowy „Strażnica” odpowiadając na pytanie czytelnika stwierdzono, że: ,[...] Nie wydaje się, aby to [m.in. transplantacja organów zmarłego - przyp. K.K.] wykraczało przeciw jakiejś zasadzie biblijnej lub prawu biblijnemu"22. Kolejna publiczna wypowiedź na ten temat miała miejsce w 1968 r. Przede wszystkim, aby uchronić się od zarzutu, że Pismo Święte nic na temat transplantacji nie mówi, gdyż jest to bardzo nowoczesna forma leczenia, poczyniono stosowne zastrzeżenie już na początku. W dalszej części powołując się na ten sam fragment Biblii, który wedle wyznawców Jehowy zabrania im przetaczania krwi uznano, że przeprowadzanie zabiegów transplantacyjnych jest równoznaczne ze spożywaniem innych ludzi. W odpowiedzi na zapytanie czytelnika odnośnie do możliwości przeszczepów wskazano, że: „Bóg pozwolił ludziom jeść mięso zwierzęce i podtrzymać życie ludzkie przez zabieranie życia zwierzętom, chociaż nie wolno im było spożywać krwi. Czy to obejmowało również jedzenie mięsa ludzkiego, podtrzymywanie życia za pomocą ciała czy części ciała, innego człowieka, żywego bądź umarłego? Żadną miarą! To byłby kanibalizm, ludożerstwo, czym brzydzi się każdy cywilizowany

Małgorzata Szeroczyńska, Bogusława Wołoszczuk-Gębicka, i Tadeusz Wiwatowski, Zabiegi chirurgiczne u Świadków Jehowy; aspekty medyczne i prawne (Warszawa: Wydawnictwo Emu, 2001), 21-49.

21 „Jesteś cudownie stworzony,” Przebudźcie się! 10 (1960): 3.

${ }^{22}$ „Pytania czytelników: Czy w Biblii znajduje się jakaś wypowiedź przeciwko udzielaniu zezwoleń na przeszczepienie po śmierci swych oczu na osobę żyjącą?", Strażnica 6 (1962): 14. 
lud na świecie. Jehowa czyni wyraźną różnicę między życiem ludzkim a życiem zwierząt, ponieważ ludzkość została stworzona na podobieństwo Boże, wyposażona w Jego właściwości, [...] Kto jednak poddaje się takim zabiegom, ten po prostu żyje kosztem ciała innego człowie$\mathrm{ka}^{23}$. Ponadto pojawiło się także odwołanie do słów św. Pawła z listu do Rzymian, który zachęcał braci: „A zatem proszę was, bracia, przez miłosierdzie Boże, abyście dali ciała swoje na ofiarę żywą, świętą, Bogu przyjemną, jako wyraz waszej rozumnej służby Bożej”24. Z racji dosłownego rozumienia przez Świadków Jehowy słów Biblii, zdanie to w ich przekładzie oznacza, że wyznawca Jehowy ma prawo i obowiązek powierzania swego życia i swego ciała Jehowie i tylko jemu, co wyklucza możliwość oddania swego ciała do dyspozycji lekarzy ${ }^{25}$.

W 1982 r. stanowisko Świadków Jehowy w kwestii transplantacji organów uległo zmianie, chociaż jak twierdzą przywódcy Organizacji na łamach swoich czasopism i stron internetowych zawsze opowiadali się za takim rozwiązaniem, a słowa wypowiedziane w 1968 r. zostały błędnie odczytane. Stwierdzono, że: „Zabranie określonej tkanki lub kości jednemu człowiekowi i przeszczepienie jej drugiemu jest sprawą, którą każdy Świadek Jehowy musi rozstrzygnąć zgodnie z własnym sumieniem" ${ }^{26}$. Oznacza to, że od tej pory każdy Świadek Jehowy miał prawo zadecydować czy zgadza się na przeszczep organu czy też nie. Ale każda decyzja była akceptowana przez zbór i nie mogła za sobą pociągnąć wykluczenia. O tym, że wyraźnie w tej materii zmieniono zdanie w stosunku do wcześniejszego stanowiska świadczy dalsza część odpowiedzi: „Inni szczerzy chrześcijanie doby dzisiejszej uważają, że Biblia nie wyklucza jednoznacznie transplantacji organów. Rozumują w ten sposób, że są wypadki, w których ludzki przeszczep wcale nie ma

${ }^{23}$ „Pytania czytelników: Czy istnieje jakieś oparte na Piśmie świętym zastrzeżenie co do ofiarowania swego ciała na badania medyczne albo przyjmowania z takiego źródła narządów celem ich przeszczepienia?- W.L.”, Strażnica 14 (1968): 13.

${ }^{24}$ List do Rzymian, 12: 1, Pismo Święte Starego i Nowego Testamentu, Biblia Tysiaclecia, 1287.

${ }^{25}$ „Pytania czytelników: Czy istnieje jakieś oparte na Piśmie świętym zastrzeżenie,” Strażnica 14 (1968): 14.

${ }^{26}$ Szerzej na temat stanowiska Świadków Jehowy wobec przeszczepu zob.: http:// swiadkowiejehowy.com.pl/dsfgd/134-transplantacja-organ\%C3\%B3w-czy-sprzeczna-z-biblia. html [dostęp: 24.09.2015]; http://onlytruegod.org/jwstrs/MCB-transp.htm [dostęp: 24.09.2015] 
pozostać trwale częścią składową organizmu biorcy. Istnieje pogląd, iż komórki ciała wymieniają się mniej więcej co siedem lat, i to dotyczyłoby również każdego przeszczepionego narządu. Można by też argumentować, że transplantacja różni się od kanibalizmu, gdyż dawca nie musi być uśmiercony dla dostarczenia pożywienia"27. Ale wciąż pojawia się wyraźne podkreślenie, że jeżeli przeszczep jest połączony z transfuzją krwi to taka czynność jest zabroniona. Także w dniu dzisiejszym to sumieniu członków zgromadzenia Świadków Jehowy pozostawia się dokonanie wyboru czy zgodzić się na przeszczep czy też nie.

W kwestii przeszczepów szpiku kostnego Ciało Kierownicze wypowiedziało się w 1985 r. ogłaszając, że pomimo, iż krwinki czerwone pochodzą ze szpiku kostnego zakaz transfuzji krwi nie może być w prosty sposób rozciągnięty na zakaz przeszczepu szpiku kostnego. Jako uzasadnienie podano, że mięso, którego spożywania Biblia nie zakazuje, nawet po wykrwawieniu się zwierzęcia zawsze zawiera pewną ilość krwi w szpiku. W związku z tym uznano, że każdy Świadek Jehowy musi sam zadecydować, czy zgadza się na przeszczep szpiku, czy też nie. Ponadto podkreślono, że wykonywanie zabiegów przeszczepu szpiku kostnego często jest połączone z koniecznością transfuzji choćby płytek krwi i dlatego wymaga dogłębnej analizy członka zboru ${ }^{28}$.

\section{STANOWISKO ŚWIADKÓW JEHOWY WOBEC SZCZEPIEŃ}

Zagadnienie stosunku Świadków Jehowy do szczepionek sięga pierwszej połowy XX w. W 1927 r. przywódcy Organizacji na łamach czasopisma „Złoty Wiek” ukazali szczepienie jako oszustwo, które prowadzi do chorób i jako takie zostało ono odrzucone. Dwa lata później w 1929 r. w tej samej gazecie szczepienie nazwane zostało zbrodnią, a choroby, którym szczepienie miało zapobiegać uznane zostały za wentyle bezpieczeństwa, które pozwalają organizmowi na wyzdrowie-

${ }^{27}$ Zob.: http://swiadkowiejehowy.com.pl/dsfgd/134-transplantacja-organ\%C3\%B3w-czysprzeczna-z-biblia.html [dostęp: 24.09.2015]

${ }^{28}$ Wiwatowski, Stanowisko Świadków Jehowy, 10-11. 
nie. Wykazywano, że dotychczas szczepienie nie uratowało niczyjego życia. W 1953 r. zmieniono zdanie w materii szczepień - decyzja w tej kwestii została pozostawiona sumieniu członka zboru ${ }^{29}$.

Stanowisko takie zostało podtrzymane w 1966 r. Stwierdzono wówczas: „,Towarzystwo nie popiera żadnego ze współczesnych zastosowań krwi w medycynie, jak na przykład użycie jej w związku ze szczepionkami. Jednak w niektórych grupach społecznych szczepienie jest okolicznością po prostu nieuniknioną i decyzję co do poddania się szczepieniu surowicą, zawierającą cząstki krwi i przeznaczoną do zbudowania przeciwciał zwalczających chorobę, pozostawiamy sumieniu każdego z osobna. Jeśli ktoś to robi, może niekiedy czerpać pociechę z faktu, że nie spożywa bezpośrednio krwi, co jest wyraźnie zakazane w Słowie Bożym. Nie zostaje ona użyta jako pokarm ani w celu zastąpienia utraconej krwi. Chrześcijanin musi tu podjąć osobistą decyzję w oparciu o własne sumienie"30.

\section{PODSTAWY PRAWNE DZIAŁAŃ PODEJMOWANYCH PRZEZ LEKARZA}

Lekarz, wedle prawa jest podmiotem zobowiązanym do niesienia pomocy medycznej. Świadczą o tym słowa przysięgi Hipokratesa, która stanowi pierwowzór dzisiejszej przysięgi, którą składają lekarze. W swej oryginalnej wersji przysięga głosiła: „[...] Będę stosował zabiegi lecznicze, wedle mych możności i rozeznania ku pożytkowi chorych, broniąc ich od uszczerbku i krzywdy. [...] Do jakiegokolwiek wejdę domu, wejdę doń dla pożytku chorych, nie po to, żeby świadomie wyrządzać krzywdę lub szkodzić w inny sposób [...]"31. Podobnie obowiązki lekarskie widzi Deklaracja Genewska podpisana w 1948 r., nowelizowana już kilkakrotnie, która zawiera tekst przysięgi lekarskiej, zobowiązującej lekarza między innymi do niedopuszczenia do sytuacji,

${ }^{29}$ Zob. http://www.piotrandryszczak.pl/medycyna.html [dostęp: 24.09.2015]

${ }^{30}$ „Praca zarobkowa a twoje sumienie; wstrzymywanie się od krwi," Strażnica 11 (1966): 12.

${ }^{31}$ Anna Nawrocka, Etos $w$ zawodach medycznych (Kraków: Wydawnictwo WAM, 2008), 68 . 
w której względy wieku, choroby lub niepełnosprawności, wyznania, pochodzenia etnicznego, płci, narodowości, przynależności politycznej, rasy, orientacji seksualnej, pozycji społecznej lub jakikolwiek inny czynnik przeszkadzał $\mathrm{w}$ stosunkach pomiędzy obowiązkiem lekarza a jego pacjentem ${ }^{32}$.

Wydaje się, że zapis ten może być rozumiany w dwojaki sposób; po pierwsze, że lekarz nie może uzależniać udzielenia pomocy medycznej od płci, wieku, orientacji seksualnej, wyznania pacjenta czy też innych czynników wymienionych w Deklaracji. Ale sformułowanie Deklaracji daje także podstawę do uznania, że zobowiązuje ona lekarza do należytego wykonywania swego zawodu, a czynniki wskazane w katalogu Deklaracji nie mogą stać się przyczyną, dla której lekarz odmówi pomocy.

W Polsce dzisiejszy tekst przysięgi lekarskiej znajdujący się w Kodeksie Etyki Lekarskiej został opracowany przez Krajowy Zjazd Lekarzy i zobowiązuje lekarzy między innymi do przeciwdziałania cierpieniu, zapobiegania chorobom i do niesienia pomocy chorym mając na celu wyłącznie ich dobro, niezależnie od m.in. ich rasy, religii, narodowości, poglądów politycznych czy stanu majątkowego ${ }^{33}$. Kodeks Etyki Lekarskiej w art. 3 stanowi, że: „Lekarz powinien zawsze wypełniać swoje obowiązki z poszanowaniem człowieka bez względu na wiek, płeć, rasę, wyposażenie genetyczne, narodowość, wyznanie, przynależność społeczną, sytuację materialną, poglądy polityczne lub inne uwarunkowania", a art. 2 ust. 2 tego aktu wyraźnie eksplikuje zasadę, która winna przyświecać lekarzowi w wypełnianiu jego zadań - salus aegroti suprema lex esto. Ponadto art. 7 Kodeksu pozwala lekarzowi na odstąpienie od leczenia lub niepodjęcie go, ale ta zasada dotyczy tylko leczenia, w szczególnie uzasadnionych przypadkach, z wyjątkiem sytuacji niecierpiących zwłoki, z jednoczesnym obowiązkiem wskazania pacjentowi innej możliwości uzyskania pomocy lekarskiej. O ile Kodeks Etyki Lekarskiej jest zbiorem norm etycznych,

${ }^{32}$ Tekst Deklaracji w języku angielskim dostępny jest pod adresem: http://www.wma. net/en/30publications/10policies/g1/ [dostęp: 24.09.2015]

${ }^{33}$ Kodeks Etyki Lekarskiej dostępny jest pod adresem: http://www.nil.org.pl/_data/ assets/pdf_file/0003/4764/Kodeks-Etyki-Lekarskiej.pdf [dostęp: 05.11.2015] 
które wedle orzeczenia Trybunału Konstytucyjnego ${ }^{34}$ nie muszą być zgodne z normą prawną $a^{35}$ o tyle żadnych wątpliwości natury prawnej nie rodzi powszechne obowiązywanie $\mathrm{w}$ systemie prawa polskiego ustawy o zawodach lekarza i lekarza dentysty ${ }^{36}$ z 1996 r. Art. 30 wspomnianej ustawy zobowiązuje lekarza do udzielenia pomocy lekarskiej zawsze, jeżeli zwłoka mogłaby spowodować groźbę utraty życia, ciężkiego uszkodzenia ciała lub ciężkiego rozstroju zdrowia oraz w innych przypadkach niecierpiących zwłoki. Art. 32 wspomnianej ustawy wymaga zgody pacjenta lub podmiotów uprawnionych do jej udzielenia na przeprowadzenie badania lub udzielenie innych świadczeń zdrowotnych ${ }^{37}$. Dodatkowo art. 33 pozwala w wyjątkowych przypadkach na wykonanie badania lub udzielenie innych świadczeń zdrowotnych bez zgody pacjenta, gdy jest to podyktowane koniecznością podjęcia niezwłocznie czynności medycznych, a stan zdrowia pacjenta lub jego wiek uniemożliwiają wyrażenie zgody, a także nie ma możliwości porozumienia się z przedstawicielem ustawowym lub opiekunem faktycznym. W takich okolicznościach ustawa zobowiązuje lekarza do skonsultowania się w miarę możliwości z innym lekarzem oraz do odnotowania zdarzenia $\mathrm{w}$ dokumentacji medycznej pacjenta. Ponadto, art. 35 przewiduje, że gdy w czasie wykonywania zabiegu operacyjnego lub stosowania metody diagnostycznej czy leczniczej wystąpią okoliczności, które mogłyby spowodować niebezpieczeństwo utraty życia, ciężkiego uszkodzenia ciała lub ciężkiego rozstroju zdrowia, a nie ma realnej możliwości uzyskania bez zbędnej zwłoki zgody pacjenta lub jego przedstawiciela ustawowego, wówczas lekarz ma prawo zmodyfikowania zabiegu czy metody leczenia lub diagnostyki w celu ochrony pacjenta bez uzyskania na takie czynno-

${ }^{34}$ Postanowienie Trybunału Konstytucyjnego z dnia 7 października 1992 r., sygn. akt U $1 / 92$.

${ }^{35}$ Szersze omówienie tego zagadnienia jest dostępne pod adresem: http://knpmif. wordpress.com/orzecznictwo/tk-u-192/ [dostęp: 05.11.2015]

${ }^{36}$ Tekst jedn.: Dz. U. z 2015 r., poz. 464 z późn. zm.

${ }^{37}$ Kwestia zgody pacjenta, w tym pacjenta małoletniego oraz obowiązku lekarza udzielania pomocy zostaną w niniejszym tekście jedynie zaznaczone. Szerzej na ten temat zob.: Elżbieta Zatyka, Lekarski obowiązek udzielenia pomocy (Warszawa: Oficyna Wolters Kluwer Business, 2011). 
ści zgody. Warunkiem jest, aby w miarę możliwości zasięgnął opinii innego lekarza najlepiej o takiej samej specjalności. Wówczas lekarz ma obowiązek poinformować pacjenta, przedstawiciela ustawowego, opiekuna faktycznego lub sąd opiekuńczy o wystąpieniu okoliczności usprawiedliwiających działanie bez zgody i zobowiązany jest dokonać stosownej adnotacji w dokumentacji medycznej. Inne warunki prawo przewiduje dla podjęcia zabiegu operacyjnego lub skorzystania z metody leczenia lub diagnostyki stwarzającej podwyższone ryzyko dla pacjenta (art. 34 omawianej ustawy). W takiej sytuacji konieczne jest uzyskanie pisemnej zgody pacjenta.

W tym miejscu pojawia się pytanie: jak ma zachować się lekarz w takiej sytuacji, jeżeli pacjent z przyczyn religijnych odmawia poddania się czynności medycznej mogącej uratować mu życie? Obowiązkiem lekarza jest działanie dla dobra pacjenta wedle reguły: salus aegroti suprema lex esto. Czy w związku z tym ma uszanować wolę pacjenta narażając się na naruszenie obowiązku wynikającego $\mathrm{z}$ art. 30 ustawy o zawodach lekarza i lekarza dentysty, czy pomimo braku zgody wykonać zabieg, co do którego pacjent wyraża sprzeciw i narazić się na ryzyko odpowiedzialności karnej z art. 192 kodeksu karnego z 1997 r. ${ }^{38}$, cywilnej z art. 444-448 kodeksu cywilnego ${ }^{39}$ czy też zawodowej z ustawy o izbach lekarskich ${ }^{40}$ ? Wydaje się, że z wyjątkiem sytuacji nadzwyczajnych wskazanych w ustawie o zawodach lekarza i lekarza dentysty, w każdym innym przypadku zgoda pacjenta warunkuje legalność zabiegu ${ }^{41}$. Sami lekarze mają tego świadomość „W takich sprawach z jednej strony mamy niedosyt i gorycz lekarzy, ale $\mathrm{z}$ drugiej - przekonania religijne. Trzeba je uszanować. Dopóki prawo się nie zmieni, lekarze będą mogli tylko przekonywać pacjenta"

${ }^{38}$ Dz. U. Nr 88, poz. 553 z późn. zm. Zob. Kodeks karny, część szczególna; komentarz do art. 117-277 kodeksu karnego, t. II, red. Andrzej Zoll (Kraków: Kantor Wydawniczy Zakamycze, 2006), 555-564.

${ }^{39}$ Dz. U. z 1964 r. Nr 16, poz. 93 z późn. zm.

${ }^{40}$ Dz. U. z 2009 r. Nr 219, poz. 1708 z późn. zm.

${ }^{41}$ Zob. szerzej na ten temat: Katarzyna Żukowska, Lekarz wobec transfuzji krwi u Świadków Jehowy, tekst jest dostępny pod adresem:http://www.prawoimedycyna.pl/ index.php?str=artykul\&id=1047\&PHPSESSID $=0 \mathrm{ff} 42733 \mathrm{f} 81 \mathrm{f} 3 \mathrm{~b} 45 \mathrm{e} 0 \mathrm{fe} 7 \mathrm{bf55b} 756378$ [dostęp: 24.09.2015] 
(jest to fragment wypowiedzi dr. n. med. Stefana Bednarza, zastępcy Dyrektora do spraw Lecznictwa Szpitala Uniwersyteckiego w Krakowie odnośnie do sprawy śmierci pacjentki, która w związku z komplikacjami po cesarskim cięciu wymagała natychmiastowej interwencji medycznej z użyciem krwi, a odmówiła poddania się zabiegowi transfuzji krwi, przyjęcia preparatów krwiopochodnych i krwiozastępczych właśnie z uwagi na swoje przekonania religijne) ${ }^{42}$.

Dodatkowo, Świadkowie Jehowy noszą przy sobie oświadczenie ${ }^{43}$, które aktualizuje się w sytuacji, gdy zajdzie konieczność przeprowadzenia transfuzji krwi, a oni nie są w stanie ze względu na stan zdrowia wyrazić swej woli w tym zakresie. Oświadczenie to zawiera wyraźny sprzeciw wobec poddania się przetoczeniu krwi. W kwestii legalności tego oświadczenia wypowiedział się Sąd Najwyższy w orzeczeniu z 2005 r., w którym stwierdził: ,W konsekwencji należy wyrazić pogląd, że oświadczenie pacjenta wyrażone na wypadek utraty przytomności, określające wolę dotyczącą postępowania lekarza w stosunku do niego w sytuacjach leczniczych, które mogą zaistnieć w przyszłości, jest dla lekarza - jeżeli zostało złożone w sposób wyraźny, jednoznaczny i nie budzi innych wątpliwości - wiążące. Zważywszy, że oświadczenie takie stanowi zgodę lub jej antonimię, wystarczające jest zachowanie formy wymaganej dla wyrażenia zgody, przewidzianej w art. 32 ust. 7 i art. 34 ust. 3 ustawy o zawodzie lekarza"44.

\section{PACJENT - ŚWIADEK JEHOWY}

Na wstępie podkreślić trzeba to, o czym była już mowa - zasadniczo warunkiem legalności przeprowadzenia przez lekarza badania czy też zabiegu medycznego jest zgoda pacjenta. Potwierdza to również

${ }^{42}$ Zob. http://www.gazetakrakowska.pl/artykul/3525749,krakow-kobieta-zmarla-poporodzie-nie-chciala-transfuzji-krwi,id,t.html [dostęp: 26.09.2015]

${ }^{43}$ Tekst oświadczenia zob.: Tadeusz Brzeziński, Etyka lekarska (Warszawa: Wydawnictwo Lekarskie PZWL, 2002), 110.

${ }^{44}$ Postanowienie Sądu Najwyższego z dnia 27 października 2005 r., sygn. III CK 155/05, dostępne jest także pod adresem: http://www.sn.pl/sites/orzecznictwo/orzeczenia1/ iii\%20ck\%20155-05-1.pdf [dostęp: 03.11.2015] 
rozdział 5 (art. 15-19) ustawy o prawach pacjenta i Rzeczniku Praw Pacjenta $^{45}$. Tym samym powołując się na względy wyznaniowe, czyli na wolność religijną zakorzenioną w przyrodzonej godności osoby ludzkiej i w związku z prawem do samostanowienia (art. 31 ust. 2 Konstytucji Rzeczypospolitej Polskiej z 1997 r., gwarantuje, że nikt nie może zostać zmuszony do czynienia tego, czego prawo mu nie nakazuje, a art. 47 przyznaje każdemu prawo do decydowania o swoim życiu osobistym) dorosły pacjent - Świadek Jehowy może odmówić poddania się konkretnym procedurom medycznym. Pacjent nie musi tłumaczyć lekarzowi z czego wynika jego brak zgody na zabieg medyczny, ale opierając się na art. 53 Konstytucji gwarantującym każdemu wolność sumienia i religii, sprzeciw pacjenta wobec leczenia czy poddania się zabiegowi medycznemu może wynikać z jego przynależności religijnej czy opierać się na przyjętym przez pacjenta światopoglądzie.

Odmiennie przedstawia się sytuacja małoletniego, za którego odpowiadają rodzice lub opiekunowie prawni i to im prawo przyznaje możliwość wyrażenia zgody na badanie lekarskie lub inne świadczenie medyczne $^{46}$. W sytuacji nadzwyczajnej, gdy małoletni nie ma przedstawiciela ustawowego lub gdy porozumienie z nim jest niemożliwe, lub gdy szesnastoletni pacjent sprzeciwia się czynnościom medycznym konieczne jest uzyskanie zezwolenia sądu opiekuńczego na dokonanie zabiegu. Pewne trudności mogą pojawić się w odniesieniu do szczepień obowiązkowych dla dzieci, młodzieży oraz osób narażonych w szczególny sposób na zakażenia. Obowiązek szczepienia nakłada ustawa o zapobieganiu oraz zwalczaniu zakażeń $i$ chorób zakaźnych u ludzit7. Co więcej niepoddanie dziecka szczepieniu obowiązkowemu skutkuje nałożeniem grzywny według regulacji art. 115 ust. 2 kodeksu wykroczeńn ${ }^{48}$ : „Tej samej karze [karze grzywny do 1500 zł albo karze nagany] podlega, kto, sprawując pieczę nad osobą małoletnią lub

${ }^{45}$ Dz. U. z 2009 r. Nr 52, poz. 417 z późn. zm.

${ }^{46}$ Szczegółowe omówienie zagadnienia zgody na świadczenie medyczne w odniesieniu do małoletniego zob.: Katarzyna Krzysztofek, „Problematyka przeprowadzania zabiegów transfuzji krwi u świadków Jehowy w polskim porządku prawnym," Przegląd Prawa Wyznaniowego 3 (2011): 56-61.

${ }^{47}$ Dz. U. z 2008 r. Nr 234, poz. 1570 z późn. zm.

${ }^{48}$ Dz. U. z 1971 r. Nr 12, poz. 114 z późn. zm. 
bezradną, pomimo zastosowania środków egzekucji administracyjnej, nie poddaje jej określonemu w $\S 1$ szczepieniu ochronnemu [przeciwko gruźlicy lub innej chorobie zakaźnej] lub badaniu". Na lekarzu spoczywa obowiązek powiadomienia powiatowego inspektora sanitarnego o fakcie braku poddania się dorosłego lub dziecka szczepieniu obowiązkowemu i tym samym zostaje uruchomiona procedura bądź przymusowego wykonania szczepienia bądź nałożenia kar przewidzianych przez kodeks wykroczeńn ${ }^{49}$.

\section{LEKARZ - ŚWIADEK JEHOWY}

W końcu należy przyjrzeć się sytuacji, gdy to lekarz z przyczyn wyznaniowych nie może świadczyć pomocy medycznej. Podstawowym przepisem w kontekście omawianego zagadnienia jest art. 39 ustawy o zawodach lekarza i lekarza dentysty, który mówi: „Lekarz może powstrzymać się od wykonania świadczeń zdrowotnych niezgodnych z jego sumieniem, z zastrzeżeniem art. 30 [nie może powstrzymać się od świadczenia, niezależnie od sprzeciwu sumienia, jeżeli zwłoka mogłaby spowodować groźbę utraty życia, ciężkiego uszkodzenia ciała lub ciężkiego rozstroju zdrowia oraz w innych przypadkach niecierpiących zwłoki], z tym, że ma obowiązek wskazać realne możliwości uzyskania tego świadczenia u innego lekarza lub w podmiocie leczniczym oraz uzasadnić i odnotować ten fakt w dokumentacji medycznej. Lekarz wykonujący swój zawód na podstawie stosunku pracy lub w ramach służby ma ponadto obowiązek uprzedniego powiadomienia na piśmie przełożonego" ${ }^{50}$. Jest to tak zwana klauzula sumienia, nazywana także sprzeciwem sumienia, która umożliwia niewykonanie obowiąz-

${ }^{49}$ Jarosław Krasnodęmbski, Czy można zmusić pacjenta do szczepienia? http://www. infor.pl/prawo/prawa-konsumenta/prawa-pacjenta/287269,Czy-mozna-zmusic-pacjentado-szczepienia.html\# [dostęp: 24.09.2015]

${ }^{50}$ Również art. 12 ust. 2 ustawy o zawodach pielęgniarki i położnej (Dz. U. z 2011 r. Nr 174, poz. 1039 z późn. zm.) pozwala pielęgniarkom i położnym na odmowę wykonania zlecenia lekarskiego lub innego świadczenia zdrowotnego niezgodnego z ich sumieniem po spełnieniu określonych w ustawie warunków. Z racji ograniczonych rozmiarów niniejszego opracowania, zostanie w nim poruszona problematyka klauzuli sumienia tylko w odniesieniu do lekarzy. 
ku nałożonego przez prawo - w tym wypadku prawnego obowiązku niesienia pomocy pacjentom - jeżeli wykonanie takiego obowiązku sprzeciwiałoby się sumieniu lekarza, pod warunkiem, że przepisy szczególne na to zezwalają - w tym przypadku przepisem tym jest art. 39 ustawy o zawodach lekarza i lekarza dentysty. Przytoczone powyżej brzmienie art. 39 wspomnianej ustawy uległo zmianie z racji opublikowania $^{51}$ w dniu 16 października 2015 r. wyroku Trybunału Konstytucyjnego z dnia 7 października 2015 r. (sygn. akt K 12/14). W wyroku tym Trybunał uznał za niekonstytucyjny zapis zobowiązujący lekarza do wskazania pacjentowi realnej możliwości uzyskania świadczenia, którego dokonania lekarz odmówił powołując się na klauzulę sumienia, $\mathrm{u}$ innego lekarza lub w innym podmiocie leczniczym. Uzasadnieniem decyzji Trybunału w tym zakresie było powołanie się m.in. na art. 53 ust. 1 Konstytucji gwarantujący każdemu wolność sumienia i religii. Od dawna podnoszono, że zobowiązanie lekarza do wskazania pacjentowi, gdzie może wykonać świadczenie medyczne, którego on sprzeciwił się dokonać z przyczyn sumienia, jest naruszeniem zasady wolności religijnej, naruszeniem sensu wprowadzenia klauzuli sumienia, skoro każe się lekarzowi współuczestniczyć w cudzym grzechu. Tym samym dziś lekarz ma obowiązek korzystając ze sprzeciwu sumienia odnotować swoją decyzję w dokumentacji medycznej pacjenta oraz ją uzasadnić, a jeśli działa w oparciu o stosunek pracy bądź służby musi uprzednio, pisemnie poinformować swojego przełożonego - te obowiązki nie zostały przez Trybunał uznane za niezgodne z Konstytucją. Pojawia się w doktrynie pogląd, że: „Sprzeciw sumienia w przypadkach ingerencji ze swej natury nieetycznych jest wprost obowiązkiem lekarza, nawet za cenę napiętnowania, przekreślenia dalszej kariery czy pozbawienia prawa wykonywania zawodu" 52 . Dodatkowo ustawa nakłada na lekarza obowiązek przełamania klauzuli sumienia i postąpienia wbrew swemu sumieniu jeżeli zwlekanie z udzieleniem pomocy medycznej może spowodować niebezpieczeństwo utraty życia, ciężkiego uszkodzenia ciała lub ciężkiego rozstroju zdrowia, czy też w innych niecierpiących

${ }^{51}$ Dz. U. z 2015 r., poz. 1633.

52 Józef Wróbel, Człowiek i medycyna. Teologicznomoralne podstawy ingerencji medycznych (Kraków: Wydawnictwo Księży Sercanów, 1999), 120. 
zwłoki okolicznościach. Jak podnosi się w doktrynie owo sformułowanie art. $30 \mathrm{w}$ zW. z art. 39 ustawy o zawodach lekarza i lekarza dentysty mówiące o ,innych przypadkach niecierpiących zwłoki” jest zbyt ogólne i zbyt szerokie, a tym samym może powodować znaczne ograniczenie możliwości korzystania z klauzuli sumienia. Dlatego też we wspomnianym wyżej wyroku z dnia 7 października 2015 r. Trybunał Konstytucyjny stwierdził niekonstytucyjność zapisu art. 30 ustawy w zakresie w jakim pozwala na przełamanie klauzuli sumienia w ,innych przypadkach niecierpiących zwłoki”. Trybunał orzekł, że zapis ten ,jest niezgodny z zasadą prawidłowej legislacji wywodzoną z art. 2 Konstytucji Rzeczypospolitej Polskiej i art. 53 ust. 1 w związku z art. 31 ust. 3 Konstytucji" "53. Wątpliwości budzi stwierdzenie mówiące o konieczności „uprzedniego” poinformowania przełożonego o zamiarze skorzystania z klauzuli sumienia w wypadku, gdy lekarz pozostaje w stosunku pracy lub służby. Nie jest jasne czy chodzi o oświadczenie uprzednie ogólne, np. przy przyjęciu do pracy lekarz uprzedza swojego przełożonego, że z powodu światopoglądu nie będzie wykonywał określonych świadczeń medycznych (do tego poglądu przychyla się w uzasadnieniu wspomnianego wyroku Trybunał Konstytucyjny); czy też poinformowanie odnosi się do konkretnej sytuacji, konkretnego pacjenta i musi być powielane za każdym razem, gdy lekarz uzna, że sumienie nie pozwala mu na podjęcie określonych świadczeń zdrowotnych $^{54}$. W tym kontekście pojawia się jeszcze jedno pytanie: czym jest „Świadczenie zdrowotne"? Jego definicja znajduje się w art. 3 ustawy o zakładach opieki zdrowotnej ${ }^{55}$ i stanowi, że są nim: ,[...] działania służące zachowaniu, ratowaniu, przywracaniu i poprawie zdrowia oraz inne działania medyczne wynikające z procesu leczenia lub przepisów odrębnych regulujących zasady ich wykonywania [...]”.

Prawo do skorzystania ze sprzeciwu sumienia gwarantują także akty prawa europejskiego. Przykładem mogą być postanowienia Karty

${ }^{53}$ Dz. U. z 2015 r., poz. 1633.

${ }^{54}$ Szerzej na ten temat zob.: Andrzej Zoll, Medycyna i prawo. O pewnych etycznoprawnych dylematach zwiazanych $z$ zaniechaniem świadczeń medycznych, tekst jest dostępny pod adresem: http://www.prawoimedycyna.pl/index.php?str=artykul\&id=266 [dostęp: 24.09.2015]

${ }^{55}$ Dz. U. z 1991 r. Nr 91, poz. 408, z późn. zm. 
Praw Podstawowych Unii Europejskiej. Karta ta w art. 10 ust. 2 stanowi: „Uznaje się prawo do odmowy działania sprzecznego z własnym sumieniem, zgodnie z ustawami krajowymi regulującymi korzystanie $\mathrm{z}$ tego prawa" ${ }^{56}$. Ponadto prawo to można wywieść także $\mathrm{z}$ art. 9 Europejskiej Konwencji o Ochronie Praw Człowieka i Podstawowych Wolności ${ }^{57}$ z 1950 r., który gwarantuje w sposób ogólny wolność myśli, sumienia i wyznania ${ }^{58}$.

W kontekście omawianego zagadnienia należy rozważyć czy lekarz będący Świadkiem Jehowy ma możliwość zarówno od strony prawnej jak i od strony światopoglądowej, religijnej nie podejmować czynności, które w świetle doktryny Świadków Jehowy są zakazane.

Od strony prawnej wskazana powyżej klauzula sumienia pozwala lekarzowi - Świadkowi Jehowy na powstrzymanie się od świadczeń zdrowotnych, w tym aplikowania pacjentom transfuzji krwi, przeprowadzania transplantacji organów czy szpiku kostnego, pod warunkiem, że zwłoka w podjęciu owych czynności nie spowoduje niebezpieczeństwa utraty życia, ciężkiego uszkodzenia ciała lub ciężkiego rozstroju zdrowia. Art. 3 ustawy o zakładach opieki zdrowotnej pośród przykładowych świadczeń zdrowotnych wymienia zapobieganie powstawaniu urazów i chorób poprzez m.in. szczepienia ochronne. Oznacza to, że lekarz może również powołując się na klauzulę sumienia odmówić wypisania skierowania na szczepienia ochronne czy też wykonania takiego szczepienia jeśli ich niewykonanie nie jest obarczone groźbą utraty życia, ciężkiego uszkodzenia ciała czy ciężkiego rozstroju zdrowia.

Od strony religijnej - na pewno lekarz należący do Organizacji Świadków Jehowy nie może przyjąć transfuzji krwi pełnej, a w kwestii szczepienia, transplantacji szpiku kostnego lub narządów musi podjąć decyzję w oparciu o swoją wiedzę, doktrynę głoszoną przez Świadków Jehowy oraz o własne sumienie. Jednakże w razie poddania się

${ }^{56}$ Dz. Urz. UE C 326 z 26.10.2012, s. 397.

${ }^{57}$ Dz. U. z 1993 r. Nr 61, poz. 284.

${ }^{58}$ Zob. Oktawian Nawrot, „Klauzula sumienia w zawodach medycznych w świetle standardów Rady Europy," Zeszyty Prawnicze Biura Analiz Sejmowych Kancelarii Sejmu 3(35) (2012): 11-16.; Jolanta Waszczuk-Napiórkowska, „Opinia prawna dotycząca wolności sumienia w konstytucjach krajów Unii Europejskiej," Zeszyty Prawnicze Biura Analiz Sejmowych Kancelarii Sejmu 3(35) (2012): 234. 
transplantacji czy szczepieniu nie poniesie z tego powodu konsekwencji w postaci wykluczenia ze zboru. Natomiast inna jest sytuacja, gdy to lekarz - Świadek Jehowy ma dokonać na pacjencie transfuzji krwi, przeszczepu czy też czynności związanych z poddaniem się szczepieniu ochronnemu. Odnośnie do przeszczepu czy to narządów czy szpiku kostnego lekarz Świadek Jehowy może dokonać takiego świadczenia zdrowotnego zarówno wobec innych Świadków Jehowy jak i „ludzi ze świata", gdyż nie jest to zakazane doktrynalnie w Organizacji. Jednakże jeśli uzna, że sprzeciwia się to jego sumieniu - wówczas powołując się na sprzeciw sumienia może nie podejmować się tych działań.

Inaczej wygląda sytuacja lekarza - Świadka Jehowy w odniesieniu do transfuzji krwi. W tym temacie wypowiedziało się przywództwo wyznawców Jehowy na łamach „Strażnicy” z 1966 r. powołując się na słowa zawarte w Księdze Powtórzonego Prawa: „Nie będziecie spożywać żadnej padliny. Dasz to do spożycia przechodniowi w twej miejscowości albo sprzedasz obcemu, bo ty jesteś narodem świętym dla Pana, Boga twego. Nie będziesz gotował koźlęcia w mleku jego matki" ${ }^{59}$. W tekście zamieszczonym w czasopiśmie ${ }^{60}$ nie zajęto wyraźnie stanowiska, ale wskazano, że niektórzy lekarze Świadkowie Jehowy, przeprowadzają zabiegi transfuzji krwi wobec osób nienależących do Organizacji na ich życzenie, co jak podkreślono jest dopuszczalne w świetle nauki biblijnej, ale decyzja ta jest pozostawiona sumieniu każdego członka zboru. Natomiast w oparciu o ten sam cytat wyraźnie zaznaczono, że lekarz Świadek Jehowy nie może przeprowadzać zabiegu przetoczenia krwi wobec „wiernego” członka Towarzystwa. W tym zakresie nasuwa się kolejne pytanie - jak ma postąpić lekarz wyznawca Jehowy w sytuacji gdy ma przed sobą pacjenta będącego Świadkiem Jehowy w stanie zagrażającym życiu lub zdrowiu z art. 30 ustawy o zawodach lekarza i lekarza dentysty? Sytuacja jest prostsza, jeżeli pacjent nie wyraża zgody na zabieg lub ma przy sobie oświadczenie stwierdzające jego sprzeciw wobec transfuzji. Natomiast problem

${ }^{59}$ Księga Powtórzonego Prawa 14:21 Pismo Święte Starego i Nowego Testamentu, Biblia Tysiaclecia, 186.

${ }^{60}$ „Praca zarobkowa a twoje sumienie; wstrzymywanie się od krwi,” Strażnica 11 (1966): 12 . 
może się pojawić, gdy lekarz zna przynależność wyznaniową pacjenta, który pomimo wszystko wyraża zgodę na przetoczenie krwi łamiąc doktrynalne zasady wyznawców Jehowy. W tej sytuacji od strony religijnej lekarz wykonując zabieg zgodnie $\mathrm{z}$ wolą pacjenta narażałby się na współudział w cudzym grzechu. Jednakże, jeśli sytuacja jest nagła, zagrażająca pacjentowi, prawo polskie na pierwszym miejscu stawia dobro pacjenta, zatem lekarz musiałby przełamać swój sprzeciw sumienia i zabieg wykonać. W przeciwnym razie ponosiłby odpowiedzialność, w związku z narażeniem życia i zdrowia pacjenta.

\section{PODSUMOWANIE}

Aktualnie ustawodawstwo polskie chroni zarówno wolność sumienia i religii, jak i prawo do samostanowienia. Wolność religijna zagwarantowana konstytucyjnie znajduje także swój wyraz w postaci klauzuli sumienia umożliwiającej lekarzowi powstrzymanie się od udzielenia świadczenia zdrowotnego niezgodnego z jego sumieniem. Po wtóre wolność ta jest zapewniona poprzez uzależnienie podjęcia czynności medycznych, takich jak np. badanie czy leczenie od zgody pacjenta. $\mathrm{Z}$ zasady samostanowienia wynika także prawo do wyrażenia sprzeciwu wobec określonych procedur medycznych niedających się pogodzić z wyznaniem pacjenta. $\mathrm{Z}$ drugiej strony, prawodawca chroniąc takie dobra jak życie czy zdrowie jednostki, nie pozwala, aby sprzeciw sumienia lekarza miał pierwszeństwo, podczas gdy zwłoka w podjęciu działania groziłaby pacjentowi możliwością utraty życia czy zdrowia. W tej sytuacji prawo ustanawia prymat działania na rzecz dobra pacjenta, ponad wolnością religijną lekarza. Te zasady są szczególnie istotne w kontekście Świadków Jehowy, którzy występują zarówno w roli pacjentów jak i lekarzy. Przyjęte przez nich wyznanie kategorycznie zabrania im poddawania się zabiegowi transfuzji krwi pełnej, natomiast przyjęcie szczepionki czy przeszczepu szpiku kostnego lub narządu pozostawia decyzji ich sumienia. Dlatego też wydaje się, że należy postulować, aby wyznawcy Jehowy nie wybierali takich specjalności, w których nieuchronnie i często będą się stykać z koniecznością podjęcia decyzji, na które wpływ będzie miał fakt ich przynależności do 
związku wyznaniowego Świadków Jehowy. Oczywiście można sobie wyobrazić, że będą oni unikać podejmowania działań medycznych wątpliwych moralnie z punktu widzenia ich światopoglądu religijnego. Ale cały czas należy pamiętać, że pracy lekarza winna przyświecać jedna zasada: zdrowie chorego jest najwyższym prawem i w sytuacji krytycznej Świadek Jehowy będący lekarzem musi podjąć niezbędne z punktu widzenia medycznego działania, nawet jeśli są one niezgodne z doktryną religii, którą wyznaje i nawet jeśli podjęcie tych czynności zamknie mu drogę do zbawienia.

\section{BIBLIOGRAFIA}

Bagiński, Elizeusz. Siewcy kąkolu; historia i wierzenia Świadków Jehowy. Kraków: Wydawnictwo Karmelitów Bosych, 1998.

Bagiński, Elizeusz. Świadkowie Jehowy od wewnątrz. Kraków: Wydawnictwo Karmelitów Bosych, 1999.

Bagiński, Elizeusz. Świadkowie Jehowy; pochodzenie-historia-wierzenia. Kraków: Wydawnictwo Karmelitów Bosych, 1997.

Brzeziński, Tadeusz. Etyka lekarska Warszawa: Wydawnictwo Lekarskie PZWL, 2002.

Elkowicz, Andrzej. Krótka historia zmian nauki Świadków Jehowy. Warszawa: Wydawnictwo Kompas II, 2004.

Kodeks karny, część szczególna; komentarz do art. 117-277 kodeksu karnego, t. II, red. Andrzej Zoll. Kraków, Kantor Wydawniczy Zakamycze, 2006.

Krzysztofek, Katarzyna. „Problematyka przeprowadzania zabiegów transfuzji krwi u świadków Jehowy w polskim porządku prawnym." Przegląd Prawa Wyznaniowego 3 (2011): 51-68.

Nawrocka, Anna. Etos w zawodach medycznych. Kraków: Wydawnictwo WAM, 2008.

Nawrot, Oktawian. „Klauzula sumienia w zawodach medycznych w świetle standardów Rady Europy." Zeszyty Prawnicze Biura Analiz Sejmowych Kancelarii Sejmu 3(35) (2012): 11-22.

Szeroczyńska, Małgorzata, Bogumiła Wołoszczuk-Gębicka, i Tadeusz Wiwatowski. Zabiegi chirurgiczne u Świadków Jehowy; aspekty medyczne i prawne. Warszawa: Wydawnictwo Emu, 2001. 
Waszczuk-Napiórkowska, Jolanta. „Opinia prawna dotycząca wolności sumienia w konstytucjach krajów Unii Europejskiej." Zeszyty Prawnicze Biura Analiz Sejmowych Kancelarii Sejmu 3 (35) (2012): 231-253.

Wróbel, Józef. Człowiek i medycyna. Teologicznomoralne podstawy ingerencji medycznych. Kraków 1999.

Zatyka, Elżbieta. Lekarski obowiazek udzielenia pomocy. Warszawa: Oficyna a Wolters Kluwer Business, 2011..

Zoll, Andrzej. Medycyna i prawo. O pewnych etyczno-prawnych dylematach zwiazanych z zaniechaniem świadczeń medycznych, http://www.prawoimedycyna.pl/index.php?str=artykul\&id=266 [dostęp: 24.09.2015]

Żaba, Czesław, Paweł Świderski, Zbigniew Żaba, Aneta Klimberg, i Zygmunt Przybylski. „Zgoda Świadków Jehowy na leczenie preparatami krwi aspekty prawne i etyczne." Archiwum Medycyny Sadowej i Kryminologii LVII (2007): 138-143.

Żukowska, Katarzyna. Lekarz wobec transfuzji krwi u Świadków Jehowy, http://www.prawoimedycyna.pl/index.php?str=artykul\&id=1047\&PHPSESSID=0ff42733f81f3b45e0fe7bf55b756378, [dostęp: 24.09.2015]

THE POSITION OF JEHOVAH'S WITNESSES

TO SOME MODERN MEDICAL PROCEDURES

IN THE LIGHT OF POLISH LAW

\section{Summary}

Nowadays, Jehovah's Witnesses in Poland are religious association registered under number 34 in the Register of churches and other religious organizations conducted by the Minister of the Interior and Administration. The doctrine of the Jehovah's Witnesses religious association, based on the literal interpretation of the words of Scripture, commits the members of this religious group to keep a number of orders and prohibitions. Some of them refer to issues related to the use of medical services. Today's rules forced the Jehovah's Witnesses not to take transfusion of whole blood. The decision to undergo to procedure of transplantation organ or bone marrow and vaccination has been left to the conscience of every Jehovah's Witness, but the consent to such treatment may not result in exclusion from the Organization of Jehovah's Witnesses. Because of this, appears the question of the attitude which should 
adopt both the patient - Jehovah's Witness, and the doctor - Jehovah's Witness in relation to these medical procedures.

Ttumaczenie własne autora

Key words: Jahovah's Witnesses, blood transfusion, the conscience clause, transplantation, vaccinations, freedom of conscience and religion

Słowa kluczowe: Świadkowie Jehowy, transfuzja krwi, klauzula sumienia, transplantacja, szczepienia, wolność sumienia i wyznania 